ISSN: 1858-4837; E-ISSN: 2598-019X

Volume 16, Nomor 2 (2021),

https://jurnal.uns.ac.id/region

DOI: 10.20961/region.v16i2.41254

\title{
Relationship of social characteristics and local economic development (LED) activity for slum upgrading in Batik Thematic Village Semarang City
}

\author{
A D Ulamdhani ${ }^{1}$, S Sunarti ${ }^{2}$ \\ ${ }^{1}$ Magister of Regional and City Planning, Diponegoro University, Semarang, Indonesia \\ ${ }^{2}$ Department of Regional and City Planning, Faculty of Engineering, Diponegoro \\ University, Semarang, Indonesia
}

Corresponding author's email: astrini_ulamdhani@yahoo.com

\begin{abstract}
The process of LED activities that starts from access to raw material, production, and product marketing will have an impact on the quality of settlements. The aspects of slum handling affected by LED activities include: 1) street, 2) waste, and 3) garbage. The LED activities in this research are focused on 1) the business length and 2 ) income. The two variables of LED activity and slum handling will be assessed for correlation with social characteristics including: 1) gender, 2) education, 3) length of stay, and 4) family income. Research location is in Batik Thematic Village, Semarang City. The problems at the location in the form of environmental impacts due to the LED activities have not been supported by the involvement of LED actors. The nonoptimal participation of LED actors can be seen from the lack of communal WWTP and waste banks. The purpose of this study is to examine the relationship of social characteristics and LED activities for slum upgrading. The study employed a quantitative approach, through a questionnaire technique with a population of 33 respondents. The data was processed through descriptive analysis. The results of the study illustrate that the longer the perpetrators stay, the longer the businesses start and the income get. Meanwhile, based on gender and education level, there are no relations that affect LED activities. The social characteristics and slum upgrading has strong correlation with the aspects of the street. The aspect of waste has very weak correlation, while the garbage aspect has no relation. Street aspect has high correlation because business actors get benefit from LED product access. The waste aspect has weak correlation because there are few entrepreneurs do the process independently, while the garbage aspect does not exist due to the similarity of handling and retribution.
\end{abstract}

Keywords: Relationships; Social Characteristics; LED; Slum Upgrading

Received: April 20, 2020; Accepted: June 21, 2020; Available online: July 15, 2021

Copyright $\odot$ 2021, REGION: Jurnal Pembangunan Wilayah dan Perencanaan Partisipatif 


\section{Introduction}

The definition of LED understanding, which is an economic development that does not only depend on the growth model but also depends on the historical development path, limited by region/geographical. This means that LED is a local economic potential that already exists and grows in a particular region supported by its distribution system [1]. Another understanding of LED is activities with the aim of increasing economic capacity in the economy of local communities, where the increase occurs because local resources are used more productively such as local human resources, land and other socio-economic potential [2].

The view of slum areas can be seen from the process of urbanization, where low-income residents mostly live in slums and low-quality housing with limited basic services and basic facilities [3]. The handling of slums is carried out with a special program paradigm by the government, resulting in the community getting increasingly no place in the urban planning section. An ongoing relationship is needed between improving slums and livelihoods in implementing slum settlement management programs [4].

The linkage between LED and the slum upgrading program is implemented with thematic villages. The idea of a thematic village is a joint decision in determining a topic for a unique location based on local natural, social and cultural conditions [5]. Other opinions related to thematic villages are innovations that can be used as examples of urban problems [6]. The Local Economic Development (LED) Model is an effective model in realizing an integrated empowerment program. The LED approach is also a program in poverty alleviation of urban communities, which can develop entrepreneurship in the community and increase the growth of local economic potential [7].

LED activity is a process carried out by business actors starting from input of raw materials, production processes and distribution systems for product marketing. The stages in the LED process have an impact that can cause a decrease in the quality of settlements. The impact on the distribution of raw materials and products can result in decreases in the street, while waste from the production process if not handled properly will have an impact on poor sanitation.

LED activities through the concept of Home Base Enterprises (HBE) are expected to increase income, but spatial and environmental competition can reduce the quality of settlements which results in slums [8]. Criteria for decreasing the quality of settlements in Regulation of the Minister of Public Work and Public Housing (PUPR) No. 14 of 2018 consists of 7 (seven), including 1) buildings, 2) environmental roads, 3) provision of drinking water, 4) environmental drainage, 5) waste water management, 6) waste management and 7) fire protection. Local governments have a commitment in handling slum areas, but with limited funds and capacity, it is necessary for the role of the community in supporting the handling of slums. Lack of information is the cause of the low behavior of people in managing the environment, even though people have attitudes that care about the environment. In enhancing effective actions and roles, information is an important factor [9]. 
Previous similar research, including:

First research, the title "Socio-economic influence of residents on slums in Wonokromo District, Surabaya City," [10]. The aim of this research is to find out the correlation between socioeconomic factors on slums and perceptions of slum improvement programs. The method used is quantitative and Likert methods, the results of the study are a positive relationship between income and education with the level of slums, while the perception of the slum upgrading program some people are not satisfied with the existing program. The renewal of this study examines the relationship of social characteristics to LED activities in the handling of slums.

Second research [11], title: "Revitalization of Slum Area in Semarang City with Thematic Village A Case Study Program in Bandarharjo Village, Indonesia". The background in this study is the problem of slums and handling through thematic village programs with the resulting outputs 1) good or positive community perception of the thematic village program and 2) strong city government commitment to the thematic village program. Research updates include: 1 ) different locations, 2) methods using quantitative, 3) focus is not looking at the success of thematic villages, but on the success of LEDs and the role in handling slum settlements.

The third study, [12]. Title: "Thematic villages as a form of community participation in the problems of slums in the city of Malang". The background is in the form of slum problems that are answered by the thematic village program, while the output produced is by the existence of a thematic village program in the form of 1) positive impacts on the community's economy, 2) social impacts seen from security and education getting better and 3) community initiatives are increasing in managing the environment. Research updates include: 1) different locations, 2) different methods, using quantitative, 3) research does not focus on evaluating the thematic village program, but the LED effort associated with handling slum areas.

The location focus is in Batik Thematic Village Rejomulyo, East Semarang District. The upgrading aspects of slums include: 1) street, 2) waste and 3) gerbage. Existing conditions found that there were still problems, including: 1 ) access street which were still an obstacle to their improvement and maintenance, 2) waste disposal from LED activities that did not yet have a waste treatment plant (WTTP) and 3) there was no "garbage bank", there is no management of LED waste management through the 3R system (Reuse, Reduce, and Recycle). It is hoped that LED activities supported by social characteristics can increase the role of business actors in upgrading slums in the aspects of street, waste and garbage in Batik Village. The quality of the Batik Village area has changed to become a better area with the support of batik business activities, but it is necessary to see how big the role of business actors in awareness the quality of settlements through LED business activities. The research question is "What is the relationship between social characteristics and LED activities in upgrading slums?."

The purpose of the study was to examine the relationship of social characteristics to LED activities in upgrading slums. Research objectives include: 1) identification of social 
characteristics, 2) identification of LED activities, 3) identification of slum settlement management, 4) Analyzing the relationship of social characteristics to LED activities in slum management, 4) formulating slum settlement management through social characteristics and LED activities.

\section{Methods}

Research uses a quantitative approach, to obtain information in a complete and accurate description of existing conditions [13]. The quantitative approach is expected to be able to obtain inputs in the form of general conditions and numerical description of events. The sampling technique used is the amount that corresponds to the sample size that will be used as the actual data source, by paying attention to the characteristics and distribution of the population in order to obtain a representative sample [14]. Sampling through "Quota Sampling," which is the population that has been determined. Quota sampling is chosen based on the number of respondents who have been identified through the LED membership data and with the hope of obtaining detailed information. Questionnaires were distributed through face-to-face interviews with respondents guided by the questionnaire [15].

Data collection techniques through primary surveys with closed questionnaires through interviews to respondents based on a population of business people as many as 33 , secondary surveys through statistical data and literature obtained from government agencies. The data will be analyzed "descriptively quantitatively" through the presentation of graphs which will then be described through narration, in order to obtain the relationship of social characteristics to LED activities in upgrading slums.

\section{Result and discussion}

Location, Batik Thematic Village is located in the city center with geographical characteristics of the plains, the area is close to the service trade center and is in a strategic location in the city of Semarang (corridor Peterongan - Tawang - Siliwangi), see figure 1. 


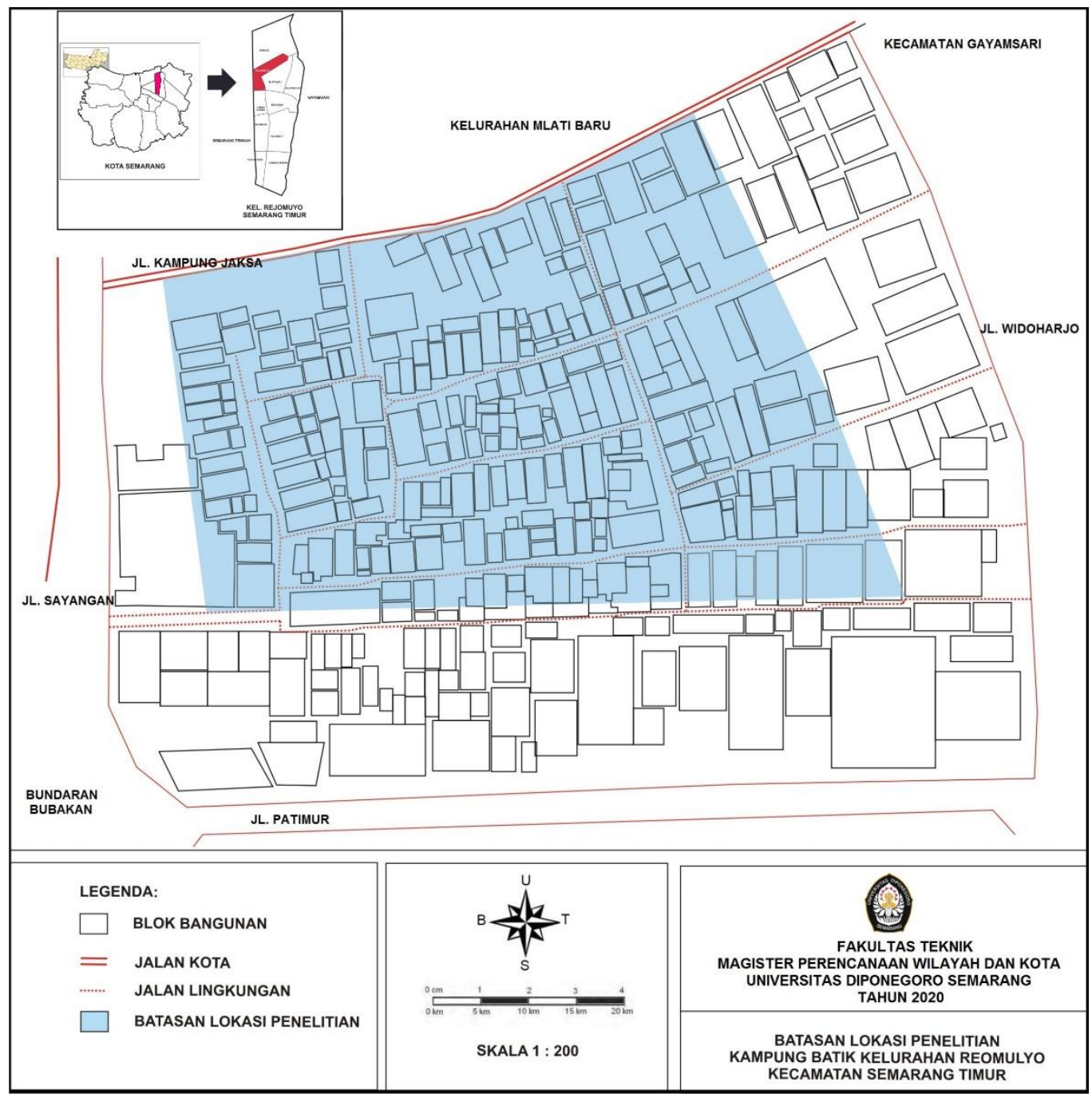

Figure 1. Location of LED in Batik Thematic Village Rejomulyo, Semarang City.

This village has existed since 1942 , batik craftsman activity at that time was still lacking and began to rise again in 1980 until 2006, although still quiet. In 2016 through the thematic village program this area began to be seriously developed by the Semarang City Government. At present Batik Rejomulyo Village is quite a lot of tourists who visit so it is crowded and become an icon of the City of Semarang.

The existence of Batik Village Rejomulyo besides batik shopping activities, this location also has activities such as 1 ) batik training for tourists and students, 2) batik exhibition on certain situational or conditions. Thematic villages are also equipped with decorations that have artistic value such as pictures and colors on the Street, walls in the batik village, so that it makes it more beautiful and attractive (see figure 2). 


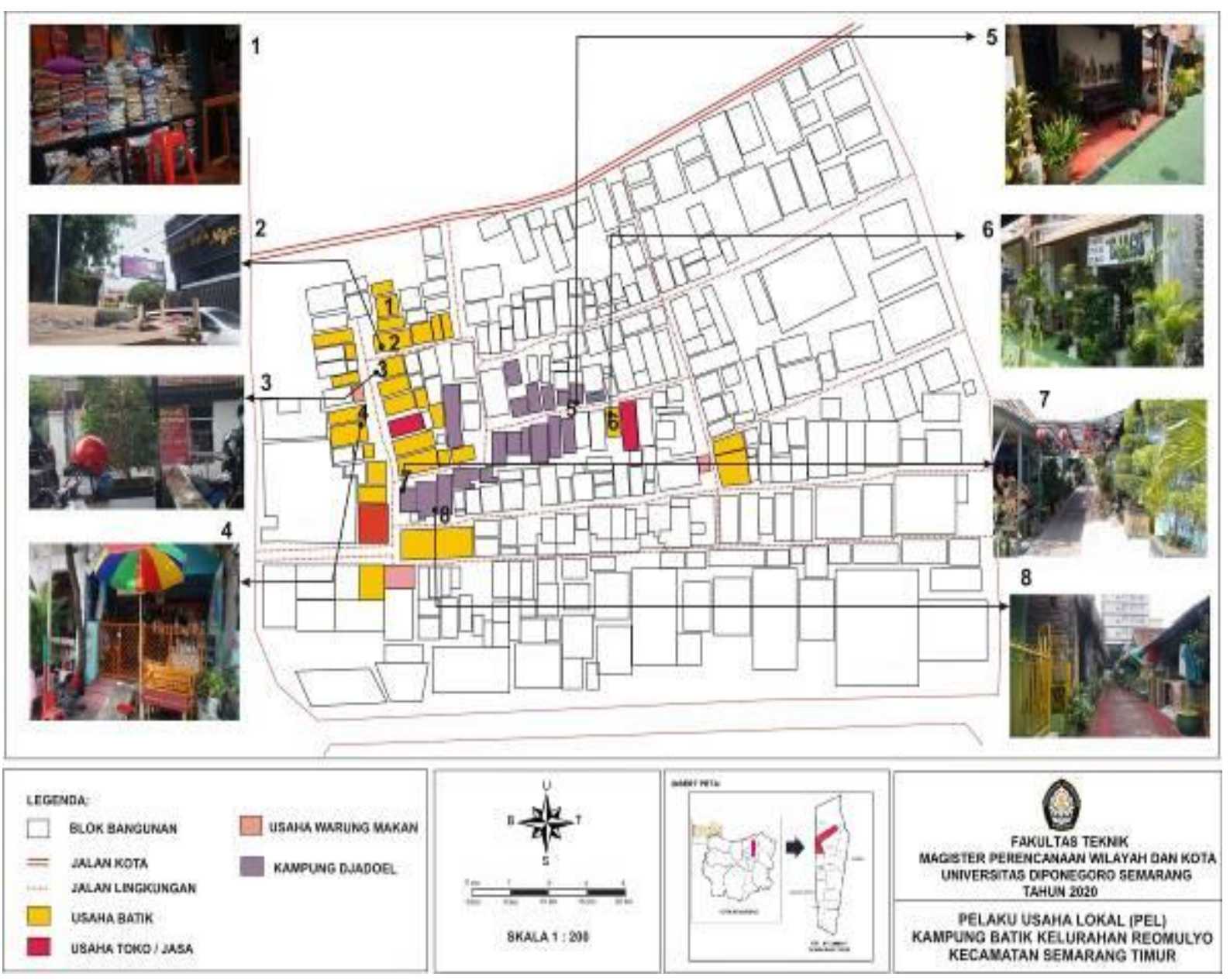

Figure 2. LED business distribution map in Batik Thematic Village Rejomulyo, Semarang City.

\subsection{Socio-economic characteristics}

The results of research conducted in Batik Thematic Village Rejomulyo, Semarang City, there were 33 respondents of LED entrepreneurs, respondent characteristics include 1) gender aspects, the majority of LED players are women by $73 \%$, and men by $27 \%, 2$ ) education aspect, the majority of LED players in Batik Village are high school graduates by $79 \%$ and D3 / S1 levels (21\%). 3) aspects of length of stay, the majority of LED players have lived in Batik Village locations for more than 10 years (78\%), and 5-10 years (21\%), 3) household income, on average at the upper middle level with the highest category at income of Rp2.750.000,00 Rp $5.000 .000,00$ by $36 \%$, income of more than Rp $10.000 .000,00$ by $30 \%$, while the category of Rp5.500.000,00 - Rp10.000.000,00 by $24 \%$, the remainder is in the category under $\mathrm{Rp} 2.700 .000,00$ at $9 \%$. More details can be seen in table 1 . 
Table 1. Socio-economic characteristics of LED entrepreneurs.

\begin{tabular}{|c|c|c|c|}
\hline No & Socio-economic characteristics & Mean & $\%$ \\
\hline \multicolumn{4}{|c|}{ 1. Gender } \\
\hline$a$ & Wowan & 24 & $73 \%$ \\
\hline \multirow[t]{2}{*}{$b$} & Man & 9 & $27 \%$ \\
\hline & Total & 33 & $100 \%$ \\
\hline \multicolumn{4}{|c|}{ 2. Last education } \\
\hline$a$ & College & 7 & $21 \%$ \\
\hline$b$ & Senior High School & 26 & $79 \%$ \\
\hline c & Junior High School & 0 & $0 \%$ \\
\hline \multirow[t]{2}{*}{$d$} & Primary school & 0 & $0 \%$ \\
\hline & Total & 33 & $100 \%$ \\
\hline \multicolumn{4}{|c|}{ 3. Length of stay } \\
\hline$a$ & Under 1 year & 0 & $0 \%$ \\
\hline b & 1 - 5 year & 0 & $0 \%$ \\
\hline c & 5 - 10 year & 7 & $21 \%$ \\
\hline \multirow[t]{2}{*}{$d$} & More than 10 years & 26 & $79 \%$ \\
\hline & Total & 33 & $100 \%$ \\
\hline \multicolumn{4}{|c|}{ 4. household income } \\
\hline a & Below less than $<$ Rp. $2.700 .000,00$ & 3 & $9 \%$ \\
\hline b & Between Rp2.750.000,00 - Rp5.000.000,00 & 12 & $36 \%$ \\
\hline c & Between Rp5.000.001 - Rp10.000.000,00 & 8 & $24 \%$ \\
\hline \multirow[t]{2}{*}{$d$} & Above more than > Rp10.000.000,00 & 10 & $30 \%$ \\
\hline & Total & 33 & $100 \%$ \\
\hline
\end{tabular}

\subsection{Characteristics of LED activity}

The economic activities of the population in Batik Village are Small and Medium Enterprises, as a batik craftsman, or distributor of batik. Based on data from respondents there were 11 batik craftsmen (33\%), batik traders or shops totaling 12 (36\%), batik tailors totaling $4(12 \%)$. In addition to business activities in the form of batik, there are 5 businesses (18\%). Raw materials are obtained from outside the location such as Pekalongan City, some production processes are carried out at the location and outside the location is still in the City of Semarang, marketing through stores or outlets in the location, as well as marketing in the city of Semarang. Look at the figure 3.

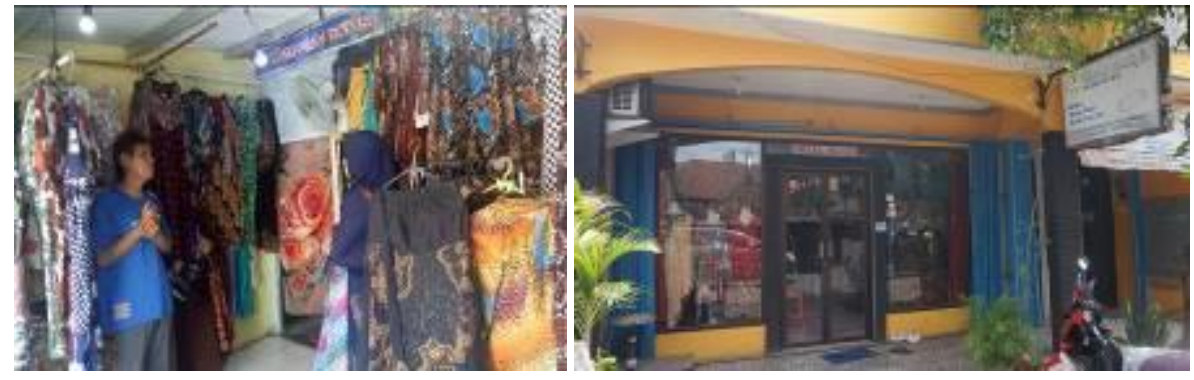

Figure 3. LED activities in the form of batik shops.

Characteristics of LED activities in Batik Village include: 1) type of LED business, the number of business operators in the batik sector is 28 entrepreneurs (85\%) while other businesses are 5 
entrepreneurs (15\%), 2) business length, the average actor has tried for more than 10 years (55\%), business duration of $4-10$ years (33\%) while business years $1-3$ years (12\%), 3) income from LED business, the majority have middle and above income with breakdown of income above Rp25.000.000,00 (21\%), revenue of Rp5.000.000,00 - Rp10.000.000,00 (42\%) and income below Rp5.000.000,00 (30\%), see table 2 .

Table 2. Characteristics of LED activities.

\begin{tabular}{|c|c|c|c|}
\hline No & Characteristics of LED Activities & Mean & $\%$ \\
\hline \multicolumn{4}{|c|}{ 1. Business Length } \\
\hline A & $1-3$ years & 4 & $12 \%$ \\
\hline B & $4-10$ years & 11 & $33 \%$ \\
\hline \multirow[t]{2}{*}{$\mathrm{C}$} & More than 10 years & 18 & $55 \%$ \\
\hline & Total & 33 & $100 \%$ \\
\hline \multicolumn{4}{|c|}{ 2. Income from LED Business } \\
\hline a & Below $<$ Rp5000.000,00 & 10 & $30 \%$ \\
\hline$b$ & Between Rp5.000.000,00 - Rp10.000.000,00 & 14 & $42 \%$ \\
\hline c & Between Rp.11.000.000,00 - Rp25.000.000,00 & 2 & $6 \%$ \\
\hline \multirow[t]{2}{*}{ d } & Above > Rp25.000.000,00 & 7 & $21 \%$ \\
\hline & Total & 33 & $100 \%$ \\
\hline
\end{tabular}

\subsection{Slum upgrading}

Atreet aspects, pavement conditions in the form of paving and an average width of $5 \mathrm{~m}$ on the main street or entrance with a width of $\pm 3 \mathrm{~m}$ in corridor. Access street are not too wide, making limitations for means of transportation in and out of the area. Narrow Street conditions also have an impact on the provision of parking and circulation which is increasingly complicated for visitors who will shop or tourists, see figure 4.
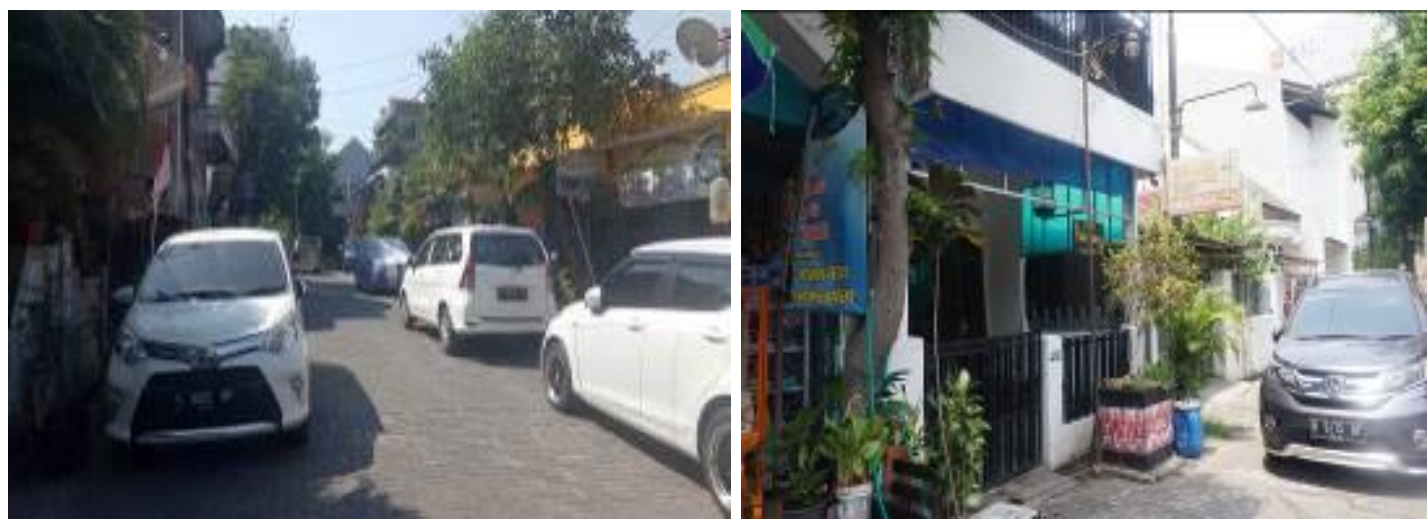

Figure 4. LED activities in the form of batik shops.

Awareness of LED actors in upgrading aspects of street including through street cleaning by $33 \%$, the next involvement is to beautify the Street (paint the street) by $33 \%$, followed by material assistance (goods) by $27 \%$ and no involvement at all by $6 \%$. The involvement of LED actors in the form of user retribution (fees) for the upgrading street, obtained results there are still many who have not been involved in street retribution with a percentage of $70 \%$, 
some respondents answered that there were contributions of more than Rp100.000,00 (21\%) and the amount between Rp21.000,00 - Rp100.000,00 (9\%). For more details, can be seen in table 3 .

Table 3. Upgrading of slums street aspects.

\begin{tabular}{crr}
\hline No $\quad$ Upgrading slum settlement street aspects & Mean & \% \\
\hline 1. Street Upgrading Forms & 2 & $6 \%$ \\
a There is no & 11 & $\mathbf{3 3 \%}$ \\
b Clean the Street & 11 & $\mathbf{3 3 \%}$ \\
c Beautify / paint the Street & 9 & $27 \%$ \\
d Giving material & 33 & $100 \%$ \\
$\quad$ Total & & \\
\hline 2. Amount of Retribution & 23 & $\mathbf{7 0 \%}$ \\
a There is no & 0 & $0 \%$ \\
b Rp5.000,00 - Rp20.000,00 & 3 & $9 \%$ \\
c Rp21.000,00 - Rp100.000,00 & 7 & $21 \%$ \\
d Above > Rp100.000,00 & 33 & $100 \%$ \\
\hline Total &
\end{tabular}

Waste aspects, an environmental condition that is directly affected by LED activities in Kampung Batik is the residual waste from the batik production process. The batik production process that produces waste is the result of laundry from coloring batik cloth. Hazardous waste from the process of making batik is usually from batik print or print. The processing of liquid waste from the batik product process is still simple, including by making simple waste receptacles flowed into the environmental drainage channel, see figure 5 .
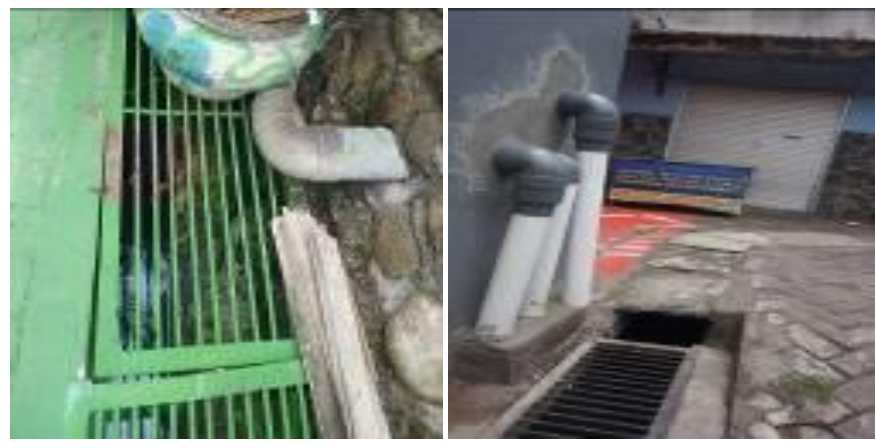

Figure 5. Drainage condition from LED activities.

Disposal of liquid waste water sourced from the batik industry is still a problem, among which there is opposition from the community, so some batik craftsmen divert production outside the location. The amount of contributions for waste management, the role of business actors in allocating funds for waste management has the largest percentage in the amount of Rp10.000,00 - Rp50.000,00 amounting to 70\% while the remaining no allocation of funds with a percentage of $24 \%$, see table 4 . 
Table 4. Upgrading of slums waste aspects.

\begin{tabular}{|c|c|c|c|}
\hline No & Upgrading slum settlement waste aspects & Mean & $\%$ \\
\hline \multicolumn{4}{|c|}{ 1. Waste Upgrading Forms } \\
\hline a & Straight to the river, sewerage & 32 & $97 \%$ \\
\hline$b$ & Waste burned & 0 & $0 \%$ \\
\hline c & Landfill waste & 0 & $0 \%$ \\
\hline \multirow[t]{2}{*}{$d$} & own sewage treatment & 1 & $3 \%$ \\
\hline & Total & 33 & $100 \%$ \\
\hline \multicolumn{4}{|c|}{ 2. Amount of Retribution } \\
\hline a & There is no & 8 & $24 \%$ \\
\hline b & Rp10.000,00 - Rp50.000,00 & 23 & $70 \%$ \\
\hline c & Rp51.000,00 - Rp200.000,00 & 1 & $3 \%$ \\
\hline \multirow[t]{2}{*}{$d$} & Above > Rp200.000,00 & 1 & $3 \%$ \\
\hline & Total & 33 & $100 \%$ \\
\hline
\end{tabular}

Garbage aspects, solid waste from batik production including packing of raw materials, materials made from wax which are the residue of tasting and "Pelorodan", garbage from trading or shopping activities in the environment. Garbage from LED activities has not been treated yet, so the garbage cans are full, this condition will have an impact on environmental health, see figure 6 .
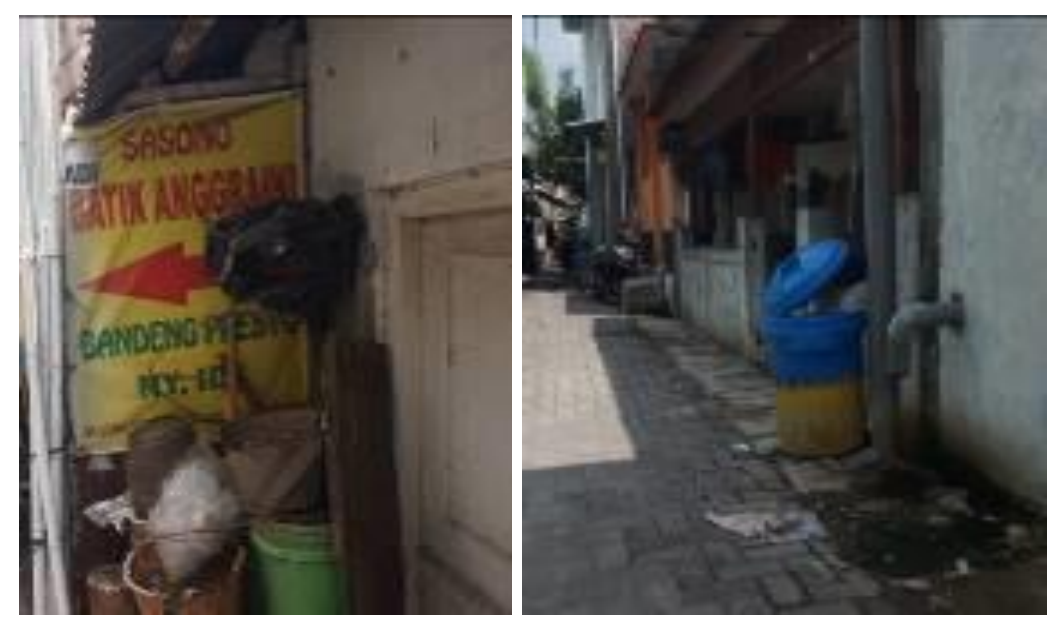

Figure 6. Garbage conditions from LED activities.

The results of the respondents disposal of garbage are disposed of through trash cans available in each house or place of business (100\%). The role of business actors in the form of funding or contributions, most business actors have allocated funds for garbage handling with a magnitude of Rp21.000,00 - Rp100.000,00 (94\%), while the remainder is in the amount of Rp5.000,00 - Rp20.000,00 (6\%), see table 5. 
Table 5. Upgrading of slums garbage aspects.

\begin{tabular}{crr}
\hline No $\quad$ Upgrading slum settlement garbage aspects & Mean & $\%$ \\
\hline 1. Garbage Upgrading Forms & & \\
a Straight to the river, sewerage & 0 & $0 \%$ \\
b Waste burned & 33 & $\mathbf{1 0 0 \%}$ \\
c Thrown in the trash & 0 & $0 \%$ \\
d Thrown itself out & 33 & $100 \%$ \\
$\quad$ Total & & \\
\hline 2. Amount of Retribution & 0 & $0 \%$ \\
a There is no & 2 & $6 \%$ \\
b Rp5.000,00 - Rp20.000,00 & 31 & $\mathbf{9 4 \%}$ \\
c Rp21.000,00 - Rp100.000,00 & 0 & $0 \%$ \\
d Above $>$ Rp100.000,00 & 33 & $100 \%$ \\
\hline Total
\end{tabular}

\subsection{Analysis relationship of social characteristics with LED activity}

The analysis is done by comparing the results of social characteristics (in the form of: gender, last education, length of stay and household income) with LED activities (in the form of: length of business and income of LED). The first comparison is between the social characteristics of LED business actors with the length of business undertaken.

The majority role of women in choosing micro-business activities is due to the view of a labor market that does not favor women (gender gap), time that is not rigid and with economic opportunities [16]. The gender characteristics at the location do not have a large influence on the length of the business, although the percentage of female business actors takes longer to start the business. The local economic drivers in Batik Village are women or housewives, the hope is that the deterioration in environmental quality due to LED activities can be balanced with the role of women entrepreneurs in helping to upgrade slums.

Educational characteristics illustrate that the higher the level of education, the higher the level of knowledge with healthy behavior in the home environment [17]. The characteristics of education at the location do not have a positive relationship with the length of effort that has been done. The education level of business operators in the majority of locations are high school and tertiary institutions, which are expected to increase the role and care of the environment that support the improvement of their businesses.

The long business relationship will affect the productivity and expertise of the actors, so that it will have an impact on efficiency, reduce production costs, increase business realization, which will ultimately increase revenue [18]. The majority of LED businesses in Batik Village have lived and made long businesses (more than 10 years). The length of time the business has been carried out is expected to be able to increase the income of business actors and have an impact on their participation in raising awareness of the environment of their settlements. The length of time the business will take will affect the amount of revenue that is quite significant [19]. The average family income of LED players in locations has a magnitude above 
the minimum regional income (UMR) of Semarang City, which has a positive relationship with a longer business period of around $10-15$ years.

The relationship between social characteristics and the length of LED business, obtained results: 1) women entrepreneurs tend to start businesses longer, 2) higher education (high school and university) has a positive relationship with business length and 3) length of stay of actors has a high correlation to the length of effort. Business operators in Batik Village have a stay of more than 10 years, so they are expected to be able to add better mental strength to the ownership (empathy) of the property in their environment. This condition is supported by the length of business that has been carried out (10-15 years), is expected to be able to increase income and environmental awareness as a result of their business activities, more details can be seen in table 6 below.

Table 6. Relationship of social characteristics with length of business (LED).

\begin{tabular}{|c|c|c|c|c|c|}
\hline \multirow{2}{*}{ No } & \multirow{2}{*}{ Socio-economic character of society } & \multicolumn{4}{|c|}{ Length of Business (LED) } \\
\hline & & 1-3 Year & 4-10 Year & 10-15 Year & $>15$ Year \\
\hline 1 & Gender & & & & \\
\hline a & Man & $6.10 \%$ & $9.10 \%$ & $9.10 \%$ & $3.00 \%$ \\
\hline \multirow[t]{2}{*}{ b } & Woman & $3.00 \%$ & $24.20 \%$ & $42.40 \%$ & $3.00 \%$ \\
\hline & Total & $9.1 \%$ & $33.3 \%$ & $51.5 \%$ & $6.1 \%$ \\
\hline 2 & Last education & & & & \\
\hline a & College & $0.00 \%$ & $6.10 \%$ & $9.10 \%$ & $3.00 \%$ \\
\hline$b$ & Senior High School & $9.10 \%$ & $27.30 \%$ & $42.40 \%$ & $3.00 \%$ \\
\hline c & Junior High School & $0.00 \%$ & $0.00 \%$ & $0.00 \%$ & $0.00 \%$ \\
\hline \multirow[t]{2}{*}{$d$} & Primary school & $0.00 \%$ & $0.00 \%$ & $0.00 \%$ & $0.00 \%$ \\
\hline & Total & $9.1 \%$ & $33.3 \%$ & $51.5 \%$ & $6.1 \%$ \\
\hline 3 & Length of stay & & & & \\
\hline a & $<1$ year & $0.00 \%$ & $0.00 \%$ & $0.00 \%$ & $0.00 \%$ \\
\hline$b$ & 1 - 5 year & $0.00 \%$ & $0.00 \%$ & $0.00 \%$ & $0.00 \%$ \\
\hline c & 5 - 10 year & $6.10 \%$ & $12.10 \%$ & $0.00 \%$ & $3.00 \%$ \\
\hline \multirow[t]{2}{*}{$d$} & $>10$ years & $3.00 \%$ & $21.20 \%$ & $51.50 \%$ & $3.00 \%$ \\
\hline & Total & $9.1 \%$ & $33.3 \%$ & $51.5 \%$ & $6.1 \%$ \\
\hline 4 & Household income & & & & \\
\hline $\mathrm{a}$ & Below less than $<$ Rp.2.700.000,00 & $0 \%$ & $3 \%$ & $3 \%$ & $3 \%$ \\
\hline$b$ & Between Rp2.750.000,00 - Rp5.000.000,00 & $6 \%$ & $12 \%$ & $18 \%$ & $0 \%$ \\
\hline c & Between Rp5.000.001 - Rp10.000.000,00 & $3 \%$ & $6 \%$ & $15 \%$ & $0 \%$ \\
\hline \multirow[t]{2}{*}{$d$} & Above more than > Rp10.000.000,00 & $0 \%$ & $12 \%$ & $15 \%$ & $3 \%$ \\
\hline & Total & $9.1 \%$ & $33.3 \%$ & $51.5 \%$ & $6.1 \%$ \\
\hline
\end{tabular}

The next comparison is between the social characteristics of business actors with income from LED business. The level of productivity in increasing income is also influenced by gender, where men are more productive than women, but entrepreneurial activities can be carried out without considering gender [18]. This opinion on gender is also seen as relevant to the conditions in the study location, where the majority of LED business operators are women, productivity can improve family welfare, with an average income of Rp5.000.000,00 Rp10.000.000,00 at $27 \%$. 
The social characteristics aspect of formal education as a variable that significantly influences the income of Micro small and medium enterprises (MSME) entrepreneurs [20]. Other income is that the characteristics of the population based on their level of education have no effect on the income of Micro small and medium enterprises (MSME) actors, education does not play an important role in entrepreneurial activities, so that it can be done by everyone with an educational background [18]. At the location there is no positive relationship between education and income, it can be seen in the results of the questionnaire that the majority of high school education that has an income above Rp25.000.000,00 is $12 \%$, while the college level is $9 \%$.

The aspect of long stay characteristic is closely related to the old aspect of the business, the business experience of the perpetrators or entrepreneurs is an important factor for small business owners / MSMEs, the more business experience means the more understanding of the character of consumers and the impact on significant income [19]. The characteristic of the length of stay of business actors at the location is more than 10 years, has a positive relationship with the level of income from the LED business on average has an income of around Rp5.000.000,00 - Rp10.000.000,00 (36\%). Economic characteristics seen from family income have a positive relationship to income from LED business, the greater the family income will be correlated with high income from LED business. Income with the largest percentage above $\mathrm{Rp} 25.000 .000,00$ (18\%) is in the family income above Rp10.000.000,00, for more details can be seen in table 7 .

Gender characteristics have a weak relationship with LED activities, education has no correlation with LED activities, length of stay has a strong relationship with LED activities and the amount of family income has a strong correlation with LED activities.

Table 7. Relationship of social characteristics with LED business income.

\begin{tabular}{|c|c|c|c|c|c|}
\hline \multirow[b]{2}{*}{ No } & \multirow[b]{2}{*}{ Socio-economic character of society } & \multicolumn{4}{|c|}{ Length of Business (LED) } \\
\hline & & 1-3 Year & 4-10 Year & $\begin{array}{l}\text { 10-15 } \\
\text { Year }\end{array}$ & $>15$ Year \\
\hline 1 & Gender & & & & \\
\hline$a$ & Man & $3.0 \%$ & $18.0 \%$ & $0.0 \%$ & $6.0 \%$ \\
\hline \multirow[t]{2}{*}{$b$} & Woman & $24.0 \%$ & $27.0 \%$ & $6.0 \%$ & $15.0 \%$ \\
\hline & Total & $27.0 \%$ & $45.0 \%$ & $6.0 \%$ & $21.0 \%$ \\
\hline 2 & Last education & & & & \\
\hline$a$ & College & $0.0 \%$ & $6.0 \%$ & $3.0 \%$ & $9.0 \%$ \\
\hline$b$ & Senior High School & $27.0 \%$ & $39.0 \%$ & $3.0 \%$ & $12.0 \%$ \\
\hline $\mathrm{c}$ & Junior High School & $0.0 \%$ & $0.0 \%$ & $0.0 \%$ & $0.0 \%$ \\
\hline \multirow[t]{2}{*}{$d$} & Primary school & $0.0 \%$ & $0.0 \%$ & $0.0 \%$ & $0.0 \%$ \\
\hline & Total & $27.0 \%$ & $45.0 \%$ & $6.0 \%$ & $21.0 \%$ \\
\hline 3 & Length of stay & & & & \\
\hline$a$ & $<1$ year & $0.0 \%$ & $0.0 \%$ & $0.0 \%$ & $0.0 \%$ \\
\hline$b$ & 1 - 5 year & $0.0 \%$ & $0.0 \%$ & $0.0 \%$ & $0.0 \%$ \\
\hline$c$ & $5-10$ year & $0.0 \%$ & $9.0 \%$ & $3.0 \%$ & $9.0 \%$ \\
\hline \multirow[t]{2}{*}{ d } & $>10$ years & $27.0 \%$ & $36.0 \%$ & $3.0 \%$ & $12.0 \%$ \\
\hline & Total & $27.0 \%$ & $45.0 \%$ & $6.0 \%$ & $21.0 \%$ \\
\hline
\end{tabular}

Received: April 20, 2020; Accepted: June 21,2020; Available online: July 15, 2021 323 


\begin{tabular}{|c|c|c|c|c|c|}
\hline \multirow[b]{2}{*}{ No } & \multirow[b]{2}{*}{ Socio-economic character of society } & \multicolumn{4}{|c|}{ Length of Business (LED) } \\
\hline & & 1-3 Year & 4-10 Year & $\begin{array}{l}\text { 10-15 } \\
\text { Year }\end{array}$ & $>15$ Year \\
\hline 3 & household income & & & & \\
\hline a & Below less than $<$ Rp. $2.700 .000,00$ & $6 \%$ & $0 \%$ & $0 \%$ & $3.0 \%$ \\
\hline $\mathrm{b}$ & Between Rp2.750.000,00 - Rp5.000.000,00 & $15 \%$ & $21 \%$ & $0 \%$ & $0.0 \%$ \\
\hline c & Between Rp5.000.001 - Rp10.000.000,00 & $6 \%$ & $18 \%$ & $0 \%$ & $0.0 \%$ \\
\hline$d$ & Above more than > Rp10.000.000,00 & $0 \%$ & $6 \%$ & $6 \%$ & $18.2 \%$ \\
\hline & Total & $27 \%$ & $45 \%$ & $6 \%$ & $21 \%$ \\
\hline
\end{tabular}

\subsection{Analysis relationship between social characteristics with upgrading of slums}

The next analysis will look at the relationship between social characteristics (education, length of stay and family income) with the form of handling slums (streets, waste and garbage). Aspects of the Street, the needs of businesses in distributing products through access Streets lead to quite high community participation, realized through thoughts, assets in the quality improvement program of slums [21]. Characteristics on aspects of gender, education, length of stay and income have a positive relationship with the form of Street handling, among the forms of handling are environmental clean, painting Streets and material assistance. Through good environmental Street access and interesting expectations, the LED business product distribution process can run smoothly and the area becomes interesting to visit, see table 8 .

The linkage of road aspects with the social characteristics of LED players is based on needs considerations, including 1 ) access to batik shops, and 2) good condition street, bright lights, clean, painted colorful colors will attract more tourists to come and buy batik products.

Table 8. Relationship between social characteristics with slum upgrading street aspects.

\begin{tabular}{lrrrr} 
& \multicolumn{1}{c}{ Social characteristics } & \multicolumn{3}{c}{ Street upgrading forms } \\
\cline { 2 - 5 } & $\begin{array}{r}\text { There } \\
\text { is no }\end{array}$ & $\begin{array}{c}\text { Clean } \\
\text { street }\end{array}$ & $\begin{array}{c}\text { Beautify } \\
\text { / paint }\end{array}$ & $\begin{array}{c}\text { Giving } \\
\text { material }\end{array}$ \\
\hline 1. Gender & & & & \\
a. Wowan & $0 \%$ & $3 \%$ & $18 \%$ & $6 \%$ \\
b. Man & $3 \%$ & $33 \%$ & $15 \%$ & $21 \%$ \\
Total & $3 \%$ & $36 \%$ & $33 \%$ & $27 \%$ \\
\hline 2. Last education & & & & \\
a. College & $3 \%$ & $0 \%$ & $9 \%$ & $6 \%$ \\
b. Senior High School & $3 \%$ & $33 \%$ & $24 \%$ & $21 \%$ \\
c. Junior High School & $0 \%$ & $0 \%$ & $0 \%$ & $0 \%$ \\
d. Primary school & $0 \%$ & $0 \%$ & $0 \%$ & $0 \%$ \\
Total & $6 \%$ & $33 \%$ & $33 \%$ & $27 \%$ \\
\hline 3. Length of stay & & & & \\
a. Under 1 year & $0 \%$ & $0 \%$ & $0 \%$ & $0 \%$ \\
b. 1 - 5 year & $0 \%$ & $0 \%$ & $0 \%$ & $0 \%$ \\
c. 5 - 10 year & $0 \%$ & $9 \%$ & $9 \%$ & $3 \%$ \\
d. More than 10 years & $3 \%$ & $27 \%$ & $24 \%$ & $24 \%$ \\
Total & $3 \%$ & $36 \%$ & $33 \%$ & $27 \%$ \\
\hline 4. Household Income & & & & \\
\hline
\end{tabular}

Received: April 20, 2020; Accepted: June 21,2020; Available online: July 15, 2021 


\begin{tabular}{rlrrrr}
\hline & \multicolumn{1}{c}{ Social characteristics } & \multicolumn{3}{c}{ Street upgrading forms } \\
\cline { 3 - 6 } & & $\begin{array}{c}\text { There } \\
\text { is no }\end{array}$ & $\begin{array}{c}\text { Clean } \\
\text { street }\end{array}$ & $\begin{array}{c}\text { Beautify } \\
\text { / paint }\end{array}$ & $\begin{array}{c}\text { Giving } \\
\text { material }\end{array}$ \\
\hline a. & Below less than $<$ Rp. $2.700 .000,00$ & $0 \%$ & $3 \%$ & $3 \%$ & $3 \%$ \\
b. & Between Rp2.750.000,00 - Rp5.000.000,00 & $0 \%$ & $15 \%$ & $12 \%$ & $9 \%$ \\
C. & Between Rp5.000.001 - Rp10.000.000,00 & $3 \%$ & $6 \%$ & $9 \%$ & $6 \%$ \\
d. & Above more than > Rp10.000.000,00 & $0 \%$ & $12 \%$ & $9 \%$ & $9 \%$ \\
Total & & $3 \%$ & $36 \%$ & $33 \%$ & $27 \%$ \\
\hline
\end{tabular}

Waste aspects, almost entirely discharged into drainage channels (97\%). Gender characteristics do not have a relationship, while education, length of stay and income have a very weak relationship, because only 1 actor does simple waste treatment (see table 9 below).

Impacts or effects of disposal of liquid waste directly to the nearest gutter or river can cause itchy skin, dry and hard skin, while the external impact is disturbing the aesthetics of the waters, reducing water quality and can affect the river's physical, chemical and biological conditions [22].Waste generated due to the washing process of batik that has been treated with hot water in order to eliminate the night. Recommended treatment for batik waste is by building a communal WWTP [23]. The above description has described the dangers of waste from the batik business, if not handled properly will cause environmental problems in the future. The role of LED business actors is needed to be more concerned with the handling of waste from the LED batik production process, by allocating space and costs for making communal WWTP.

Table 9. Relationship between social characteristics with slum upgrading waste aspects.

\begin{tabular}{|c|c|c|c|c|}
\hline \multirow{2}{*}{ Socio-economic character of society } & \multicolumn{4}{|c|}{ Waste upgrading forms } \\
\hline & Drainage & Burned & Landfill & Treatment \\
\hline \multicolumn{5}{|l|}{ 1. Gender } \\
\hline a. Wowan & $24.24 \%$ & $0.00 \%$ & $0.00 \%$ & $3.03 \%$ \\
\hline b. Man & $72.73 \%$ & $0.00 \%$ & $0.00 \%$ & $0.00 \%$ \\
\hline Total & $97.0 \%$ & $0.0 \%$ & $0.0 \%$ & $3.0 \%$ \\
\hline \multicolumn{5}{|l|}{ 2. Last education } \\
\hline a. College & $15.20 \%$ & $0.00 \%$ & $0.00 \%$ & $3.00 \%$ \\
\hline b. Senior High & $81.80 \%$ & $0.00 \%$ & $0.00 \%$ & $0.00 \%$ \\
\hline c. Junior High & $0.00 \%$ & $0.00 \%$ & $0.00 \%$ & $0.00 \%$ \\
\hline d. Primary & $0.00 \%$ & $0.00 \%$ & $0.00 \%$ & $0.00 \%$ \\
\hline Total & $97.0 \%$ & $0.0 \%$ & $0.0 \%$ & $3.0 \%$ \\
\hline \multicolumn{5}{|l|}{ 3. Length of stay } \\
\hline a. $<1$ year & $0.00 \%$ & $0.00 \%$ & $0.00 \%$ & $0.00 \%$ \\
\hline b. 1 - 5 year & $0.00 \%$ & $0.00 \%$ & $0.00 \%$ & $0.00 \%$ \\
\hline c. 5 - 10 year & $21.20 \%$ & $0.00 \%$ & $0.00 \%$ & $0.00 \%$ \\
\hline d. $>10$ years & $75.80 \%$ & $0.00 \%$ & $0.00 \%$ & $3.00 \%$ \\
\hline Total & $97.0 \%$ & $0.0 \%$ & $0.0 \%$ & $3.0 \%$ \\
\hline \multicolumn{5}{|l|}{ 4. household income } \\
\hline a. Below less than $<$ Rp. $2.700 .000,00$ & $6.10 \%$ & $0.00 \%$ & $0.00 \%$ & $0.00 \%$ \\
\hline b. Between Rp2.750.000,00 - Rp5.000.000,00 & $36.40 \%$ & $0.00 \%$ & $0.00 \%$ & $0.00 \%$ \\
\hline
\end{tabular}




\begin{tabular}{rlrrrr}
\hline & \multirow{2}{*}{ Socio-economic character of society } & \multicolumn{4}{c}{ Waste upgrading forms } \\
\cline { 3 - 5 } & Drainage & Burned & Landfill & Treatment \\
\hline C. & Between Rp5.000.001-Rp10.000.000,00 & $24.20 \%$ & $0.00 \%$ & $0.00 \%$ & $0.00 \%$ \\
d. Above more than > Rp10.000.000,00 & $30.30 \%$ & $0.00 \%$ & $0.00 \%$ & $3.00 \%$ \\
Total & & $97.0 \%$ & $0.0 \%$ & $0.0 \%$ & $3.0 \%$ \\
\hline
\end{tabular}

Garbage aspect, the rest of solid waste in the form of waste from packaging raw materials, the production process and the rest of the marketing activities of batik are disposed of through the trash cans in each house. There is no positive correlation between social characteristics and forms of waste management. All LED businesses dispose of their waste through landfills, see the following table 10 .

Good waste management is an activity carried out to handle waste from its generation to the final disposal [24]. Waste management in Batik Village is seen as not yet a major problem by business actors. Waste from the LED production process has not been managed properly, by not applying the $3 \mathrm{R}$ concept, this condition is carried out by all business operators in Batik Village. A strong correlation occurs between the social characteristics of LED actors towards the form of road handling. The waste aspect is positively related but it is very weak, while in the waste aspect there is no correlation.

Table 10. Relationship between social characteristics with slum upgrading garbage aspects.

\begin{tabular}{|c|c|c|c|c|}
\hline \multirow[b]{2}{*}{ Socio-economic character of society } & \multicolumn{4}{|c|}{ Garbage upgrading forms } \\
\hline & Drainage & Burned & $\begin{array}{c}\text { Trash } \\
\text { can }\end{array}$ & $\begin{array}{l}\text { Thrown in } \\
\text { the trash }\end{array}$ \\
\hline \multicolumn{5}{|l|}{ 1. Gender } \\
\hline a. Woman & $0.00 \%$ & $0.00 \%$ & $27.27 \%$ & $0.00 \%$ \\
\hline b. Man & $0.00 \%$ & $0.00 \%$ & $72.73 \%$ & $0.00 \%$ \\
\hline Total & $0.0 \%$ & $0.0 \%$ & $100.0 \%$ & $0.0 \%$ \\
\hline \multicolumn{5}{|l|}{ 2. Last education } \\
\hline a. College & $0 \%$ & $0 \%$ & $18.20 \%$ & $0 \%$ \\
\hline b.Senior High & $0 \%$ & $0 \%$ & $81.80 \%$ & $0 \%$ \\
\hline C. Junior High & $0 \%$ & $0 \%$ & $0.00 \%$ & $0 \%$ \\
\hline d. Primary & $0 \%$ & $0 \%$ & $0.00 \%$ & $0 \%$ \\
\hline Total & $0 \%$ & $0 \%$ & $100.00 \%$ & $0 \%$ \\
\hline \multicolumn{5}{|l|}{ 3. Length of stay } \\
\hline a. $<1$ year & $0 \%$ & $0 \%$ & $0.00 \%$ & $0 \%$ \\
\hline b. 1 - 5 year & $0 \%$ & $0 \%$ & $0.00 \%$ & $0 \%$ \\
\hline C. 5 - 10 year & $0 \%$ & $0 \%$ & $21.20 \%$ & $0 \%$ \\
\hline d. $>10$ years & $0 \%$ & $0 \%$ & $78.80 \%$ & $0 \%$ \\
\hline Total & $0 \%$ & $0 \%$ & $100.00 \%$ & $0 \%$ \\
\hline \multicolumn{5}{|l|}{ 4. household income } \\
\hline a. Below less than $<$ Rp. $2.700 .000,00$ & $0 \%$ & $0 \%$ & $9.10 \%$ & $0 \%$ \\
\hline b. Between Rp2.750.000,00 - Rp5.000.000,00 & $0 \%$ & $0 \%$ & $36.40 \%$ & $0 \%$ \\
\hline C. Between Rp5.000.001 - Rp10.000.000,00 & $0 \%$ & $0 \%$ & $24.20 \%$ & $0 \%$ \\
\hline d. Above more than $>$ Rp10.000.000,00 & $0 \%$ & $0 \%$ & $30.30 \%$ & $0 \%$ \\
\hline Total & $0 \%$ & $0 \%$ & $100.00 \%$ & $0 \%$ \\
\hline
\end{tabular}

Received: April 20, 2020; Accepted: June 21,2020; Available online: July 15, 2021 326 Copyright $@$ 2021, REGION: Jurnal Pembangunan Wilayah dan Perencanaan Partisipatif 


\subsection{Formulation of slums upgrading with approach social characteristics and LED activities}

Relevant formulation to be applied in handling slum settlements through social characteristics of LED activities, including: 1) actions to reduce waste and garbage from the LED production process and stages, 2 ) the form of "cost sharing" or financing contributions for handling slums.

Reducing waste actions through the implementation of the LCA "Life Cycle Assessment." The concept of LCA is a measure of the environmental impact of production processes and systems in supporting decisions around production and consumption, focusing on prevention factors against environmental damage [25]. The LCA concept for waste management is implemented through the selection of environmentally friendly materials and materials such as natural dyes, to create an "Eco Print" batik. Implementation in handling waste includes making waste banks, sorting waste from LED production, minimizing plastic materials, and separating waste materials by type to be distributed to waste banks.

Financing actions for the handling of slums, through the application of economics in environmental management caused by pollution from waste economic activities [26]. Financing for handling slums by applying the concept of "Environmental Management Accounting (EMA)". This concept is to answer the fees that must be donated to the environment [27]. The concept of EMA can be implemented by calculating the estimated percentage of production costs of batik allocated for handling street, waste and garbage so as to increase profits or profits for the LED business. The results of business actor user fees managed by local institutions can be used for 1 ) road handling, through maintenance, repair and beautification, 2) waste management, for WWTP space allocation, planning and construction of WWTP, management and maintenance of WWTP, 3) waste management, through the creation of a waste bank and operational management. The following table 11 and figure 9 schemes for Upgrading Slums with Approach Social Characteristics and LED Activities (see table 11 and figure 9 below).

Table 11. Concept of social characteristics and local economic development (LED) activity for slums upgrading.

\begin{tabular}{|c|c|c|c|c|}
\hline \multirow{2}{*}{$\begin{array}{l}\text { Handling } \\
\text { slum }\end{array}$} & \multirow{2}{*}{$\begin{array}{l}\text { Concept of } \\
\text { handling }\end{array}$} & \multirow{2}{*}{$\begin{array}{c}\text { Form of handling (program of } \\
\text { activities) }\end{array}$} & \multicolumn{2}{|c|}{ Role of handling } \\
\hline & & & LED business & The goverment/CSR \\
\hline $\begin{array}{l}\text { Handling } \\
\text { Street }\end{array}$ & $\begin{array}{l}\text { Environmental } \\
\text { Management } \\
\text { Accounting } \\
(\text { EMA) }\end{array}$ & $\begin{array}{l}\text { 1. Repairing street } \\
\text { 2. Road maintenance } \\
\text { 3. Damage control } \\
\text { 4. Beautify the road }\end{array}$ & $\begin{array}{l}\text { Through } \\
\text { environmental } \\
\text { retribution is used to } \\
\text { share costs for } \\
\text { programs and } \\
\text { activities. }\end{array}$ & $\begin{array}{l}\text { Sharing in the form of: } \\
\text { 1) funding, 2) physical } \\
\text { projects / activities, 3) } \\
\text { equipment assistance } \\
\text { and 4) material } \\
\text { assistance }\end{array}$ \\
\hline $\begin{array}{l}\text { Handling } \\
\text { Waste }\end{array}$ & $\begin{array}{l}\text { Life Cycle } \\
\text { Assessment } \\
\text { (LCA) }\end{array}$ & $\begin{array}{l}\text { 1. Selection of } \\
\text { environmentally friendly } \\
\text { raw materials } \\
\text { 2. Minimizing the waste of } \\
\text { the production process } \\
\text { 3. Utilization of derived } \\
\text { product waste }\end{array}$ & $\begin{array}{l}\text { Implement the } \\
\text { production process } \\
\text { through an } \\
\text { environmentally } \\
\text { friendly form of } \\
\text { handling }\end{array}$ & $\begin{array}{l}\text { Implement the } \\
\text { production process } \\
\text { through an } \\
\text { environmentally } \\
\text { friendly form of } \\
\text { handling }\end{array}$ \\
\hline
\end{tabular}




\begin{tabular}{|c|c|c|c|c|}
\hline \multirow{3}{*}{$\begin{array}{l}\text { Handling } \\
\text { slum }\end{array}$} & \multirow{2}{*}{$\begin{array}{l}\text { Concept of } \\
\text { handling }\end{array}$} & \multirow{2}{*}{$\begin{array}{c}\text { Form of handling (program of } \\
\text { activities) }\end{array}$} & \multicolumn{2}{|c|}{ Role of handling } \\
\hline & & & LED business & The goverment/CSR \\
\hline & $\begin{array}{l}\text { Environmental } \\
\text { Management } \\
\text { Accounting } \\
\text { (EMA) }\end{array}$ & $\begin{array}{l}\text { 1. Development of } \\
\text { communal WWTP } \\
\text { 2. Implementation of } \\
\text { communal WWTP } \\
\text { 3. Maintenance of } \\
\text { Communal WWTPs } \\
\text { 4. Maintenance of the } \\
\text { channel }\end{array}$ & $\begin{array}{l}\text { Through } \\
\text { environmental } \\
\text { retribution from LED } \\
\text { players who are used } \\
\text { to share costs for the } \\
\text { communal LED making } \\
\text { program }\end{array}$ & 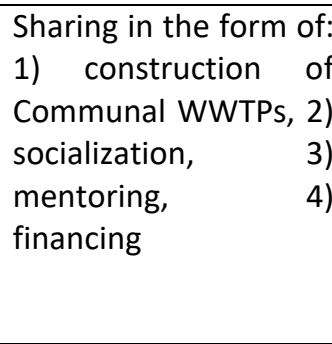 \\
\hline & $\begin{array}{l}\text { Life Cycle } \\
\text { Assessment } \\
\text { (LCA) }\end{array}$ & $\begin{array}{l}\text { 1. Selection of raw materials } \\
\text { that are environmentally } \\
\text { friendly } \\
\text { 2. Minimize plastic waste } \\
\text { 3. Utilization of beneficial } \\
\text { product waste }\end{array}$ & 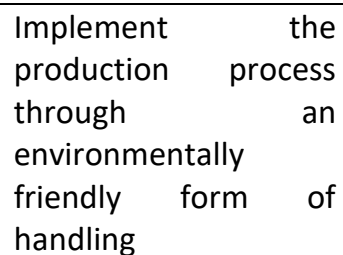 & $\begin{array}{l}\text { Sharing in the form of: } \\
\begin{array}{ll}\text { 1) socialization, 2) } \\
\text { assistance and } \\
\text { financing }\end{array}\end{array}$ \\
\hline $\begin{array}{l}\text { Handling } \\
\text { Gerbage }\end{array}$ & $\begin{array}{l}\text { Environmental } \\
\text { Management } \\
\text { Accounting } \\
\text { (EMA) }\end{array}$ & $\begin{array}{l}\text { 1. Procurement of waste bin } \\
\text { infrastructure } \\
\text { 2. Waste transportation } \\
\text { costs } \\
\text { 3. Construction of a waste } \\
\text { bank } \\
\text { 4. Waste bank maintenance }\end{array}$ & $\begin{array}{l}\text { Through } \\
\text { environmental } \\
\text { retribution from LED } \\
\text { players used for waste } \\
\text { management } \\
\text { programs }\end{array}$ & 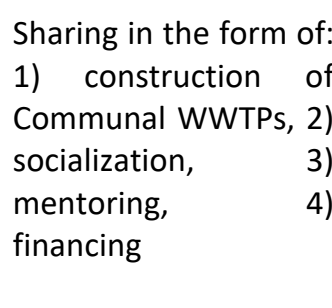 \\
\hline
\end{tabular}




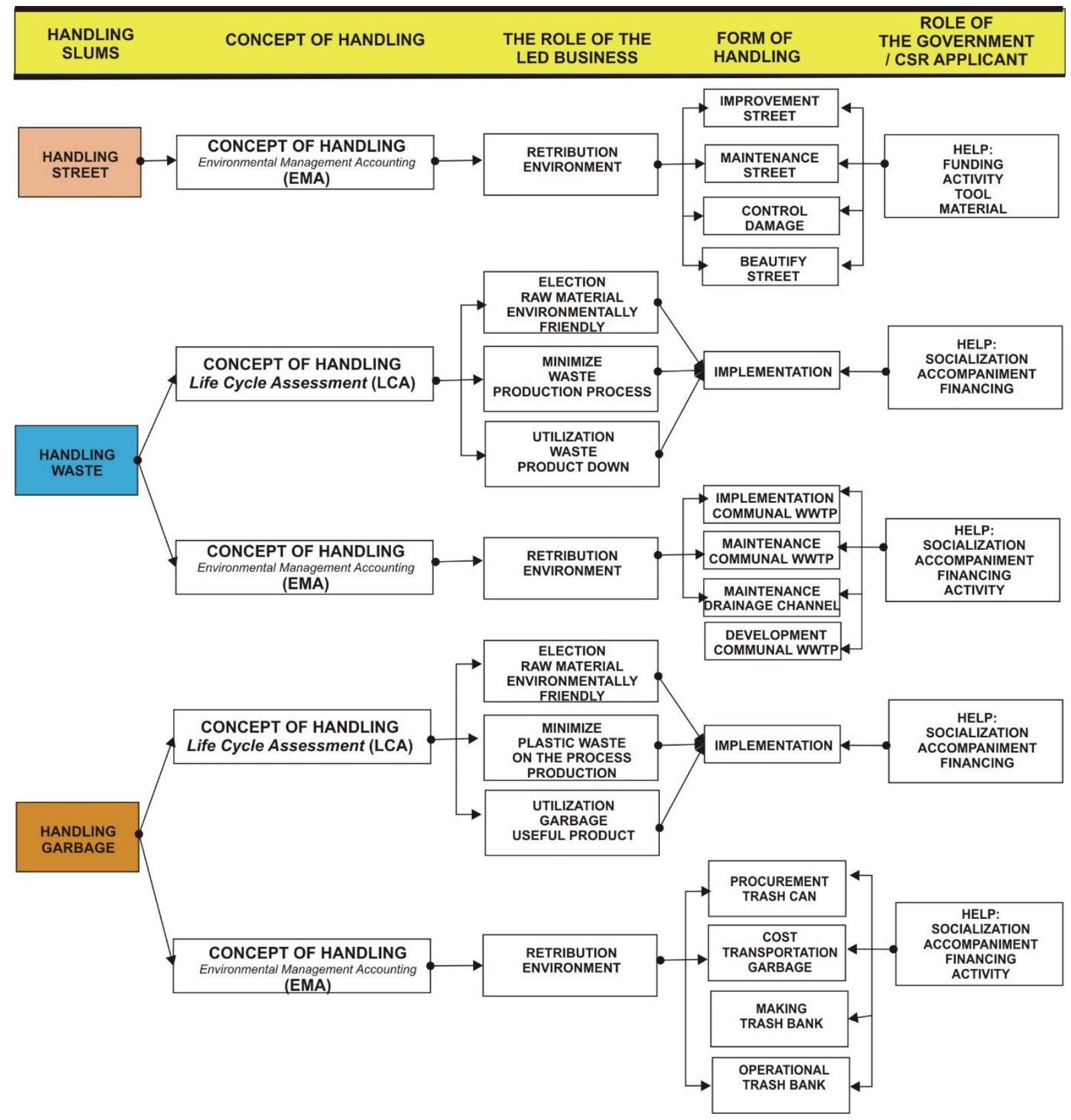

Figure 9. Scheme of social characteristics and local economic development (LED) activity for slums upgrading.

\section{Conclusions}

Social characteristics have a positive relationship with LED activities, where length of stay has a strong influence on business length and income. Gender differences and education levels have weak tendencies.

The relationship of social characteristics to LED activities in the handling of slums occurs in the form of handling street and waste. Road handling has a high correlation, business actors 
benefit from access to the distribution of LED products and tourists. Form of waste management has a very small correlation, business actors tend not to do waste treatment. Correlation does not occur in the form of handling waste due to the similarity of waste processing, namely throwing it directly into the garbage bin without handling it first.

The formulation of slum settlement management is through the involvement of LED businesses in Kampung Batik, including: 1) reduction of waste and garbage from each stage of production through the concept of Environmental Management Accounting (LCA) and 2) financing for handling street, waste and waste through the concept of Environmental Management Accounting (EMA).

Recommendation, increasing the role of LED business actors in the handling of slums, through the form of reducing waste and sharing the cost (cost sharing) of the LED business. Semarang City Government's involvement is in strengthening the existence of LED. Increased Corporate Social Responsibility (CSR) in assistance and financing for handling slums.

\section{Acknowlegments}

In this study we received data and information support from: 1) Mrs. Ida Purwanti as Chairman of RW 02, 2) Mr. Tri Utomo, SE as Chairperson of KSM Kampung Batik and 3) Kampung Batik Rejomulyo Semarang Community. For your help and support, we express our gratitude and appreciation for the input to this study.

\section{Referensi}

[1] Conti S, Giaccaria P. Local Economic Development A2 - Kitchin, Rob. International Encyclopedia of Human Geography; 2009.

[2] Bartik TJ. Local Economic Development Policies. SSRN Electron J 2003. https://doi.org/10.2139/ssrn.400820.

[3] Goswami S, Manna PS. Urban Poor Living in Slums : A Case Study of. Glob J Hum Soc Scinence Sociol Cult 2013;13.

[4] Minnery J, Argo T, Winarso H, Hau D, Veneracion CC, Forbes D, et al. Slum upgrading and urban governance: Case studies in three South East Asian cities. Habitat Int 2013;39:162-9. https://doi.org/10.1016/j.habitatint.2012.12.002.

[5] Kłoczko-Gajewska A. General Characteristics of Thematic Villages in Poland. Visegr J Bioeconomy Sustain Dev 2014.

[6] Altensperger ERB. Central European Case Studies 2012;2:9-14.

[7] Indratno I, Agustina IH. Studi Kemampuan Masyarakat dalam Pengembangan Ekonomi Lokal Sebagai Upaya Pengentasan Kemiskinan (Studi Kasus Desa Tegalurung Kecamatan Legonkulon Kabupaten Subang). MIMBAR, J Sos Dan Pembang 2005;21:415-528. https://doi.org/10.29313/mimbar.v21i3.185.

[8] Kellett P, Tipple AG. The home as workplace: A study of income-generating activities within the domestic setting. Environ Urban 2000;12:203-13. https://doi.org/10.1630/095624700101285190.

[9] Saputra A. Partisipasi Masyarakat dalam Penyusunan Rencana Tata Ruang dan Wilayah Kabupaten Bulungan 2017. 
[10] M I, Risyanto. Pengaruh Sosial Ekonomi Penghuni Terhadap Permukiman Kumuh Di Kecamatan Wonokromo Kota Surabaya. J INKOM 2014:1-8.

[11] Purnaweni H. Revitalization of Slum Area in Semarang City with Thematic Village Program -- A Case Study in Bandarharjo Village, Indonesia (PROCEEDING OF PAPER SUMMARY ICAS 2017). n.d.

[12] Akbar T. Kampung Tematik Sebagai Bentuk Partisipasi Masyarakat Dalam Permasalahan Permukiman Kumuh Di Kota Malang. Wahana 2018;70:37-48. https://doi.org/10.36456/wahana.v70i2.1741.

[13] Kuncoro M. Metode Kuantitatif; Teori dan Aplikasi untuk Bisnis dan Ekonomi. 4th ed. Yogyakarta: Sekolah Tinggi Ilmu Manajemen YKPN; 2011.

[14] Margono S. Metodologi penelitian pendidikan : komponen MKDK/S. Margono. Jakarta: Rineka Cipta; 2005.

[15] Singarimbun M. Metode Penelitian Survai. LP3ES; 1989.

[16] Dumas C. Training for Microenterprise Creation: The Case of the Center for Women and Enterprise. Int J Econ Dev 1999;1:201.

[17] Putri HP, Lingkungan DT. Life Cycle Assessment ( Lca ) Emisi Pada Proses Produksi Bahan Bakar Minyak ( Bbm ) Jenis Bensin Dengan Pendekatan Analytical Hierarchy Process ( Ahp ) 2017.

[18] Nainggolan R. Gender, Tingkat Pendidikan Dan Lama Usaha Sebagai Determinan Penghasilan Umkm Kota Surabaya. Kinerja 2016;20:1. https://doi.org/10.24002/kinerja.v20i1.693.

[19] Rani R. Pengaruh Modal Dan Lama Usaha Terhadap Pendapatan Pedagang Di Pasar Tradisional Pasar Minggu. Widya Cipta - J Sekr Dan Manaj 2019;3:143-8. https://doi.org/10.31294/widyacipta.v3i1.5264.

[20] Putra A, Basri H. Representasi Kehidupan Sosial Ekonomi Pelaku Usaha Mikro Kecil Menengah (UMKM) Dikawasan Objek Wisata Percandian Muaro Jambi-Provinsi Jambi. JBMP (Jurnal Bisnis, Manaj Dan Perbankan) 2019;5:1. https://doi.org/10.21070/jbmp.v5i1.2036.

[21] Ramdlani S. Toward Sustainable Cities and Communities, Through Revitalization of Pottery Urban Kampongs in Malang. MATTER Int J Sci Technol 2018;3:306-16. https://doi.org/10.20319/mijst.2018.33.306316.

[22] Andriani R,_H. TOKSISITAS LIMBAH CAIR INDUSTRI BATIK TERHADAP MORFOLOGI SISIK IKAN NILA GIFT (Oreochomis nilotocus). J SainHealth 2017;1:83. https://doi.org/10.51804/jsh.v1i2.108.83-91.

[23] Maria R, Sumawijaya N, Suherman D, Marganingrum M. Pengaruh Limbah Cair Industri Batik. Pros Pemaparan Has Penelit Geoteknologi LIPI 2014:591-9.

[24] Suryani. Analisis Beberapa Faktor Sosial Ekonomi Petani Yang Mempengaruhi Pendapatan Usahatani Tanaman Pangan Pada Lahan Kering Di Kabupaten Wonogiri 2012.

[25] Hauschild M.Z. Introduction to LCA Methodology. Hauschild M, Rosenbaum R, Olsen S Life Cycle Assess 2017.

[26] W HS. Hubungan antara Kelestarian Ekonomi dan Lingkungan: Suatu Kajian Literatur. Binus Bus Rev 2013;4:841-50. https://doi.org/10.21512/bbr.v4i2.1400. 
[27] Burritt R, Schaltegger S. Eco-efficiency in corporate budgeting. Environ Manag Heal 2001;12:158-74. 